\title{
Constructing the Regulatory Mechanism and Guiding the Orderly Flow of Migrant workers
}

\author{
Mei Jian \\ School of Literature and Media \\ Chongqing University of Education \\ Chongqing, 400067, China
}

\author{
Gu Shenghua \\ School of Literature and Media \\ Chongqing University of Education \\ Chongqing, 400067, China
}

\begin{abstract}
Large-scale of migrant workers' movement to the city has had a positive social impact, and in the meantime, it has also caused new problems for the society which has already affected the sustainable and scientific development of the country. It is urgent for China to construct the regulatory mechanism to control the flow rate, direction and speed of migrant workers in order to guide them to move orderly. This essay proposed a countermeasure for it.
\end{abstract}

Keywords- migrant workers, orderly flow, regulatory mechanism, flow rate, flow direction, flow speed

\section{INTRODUCTION}

Since the reform andopening-up, the flow of Chinese rurallabors (migrant workers) has gone through five periods of controlling theflow(from 1979 to 1983), allowing the flow(from 1984 -1988), controlling the blindflow (1989 1991), regulating the flow(1992 - 2000) and ensuring the fair flow (after 2000). It should be said that the policies from "controlling the flow" to "ensuring the fair flow" have itspositivesocial significance in a particular historical period.However, things are alwaysdivided into two sides! According to the Investigation and Monitoring Report of Chinese Migrant Workers in 2011 made by NationalBureau of Statistics, the total amount of Chinese migrant workersis25278. During the 4years from2008 to 2011, the total amount ofmigrant workers entering the citiesincreased by $4 \%-6 \%$ every year, and the migrant workers increased tens of millions every year. The largecontingentof migrant workers entering the cities hasits positivesocial significance, but it has also triggered a series ofnew socialproblems which has affected thecountry'sscientific and sustainable development!Please seethe followingfacts:

Many rural areas have been "empty", and a large number of farmlands are abandoned, bringingdirect threat to our food security. More and more children move into the cityto go to school followingtheir parents, causing the insufficiencies of the education and teaching resourcesin city schools and the idle and waste of education and teaching resources in ruralschools as the amount of rural students reduce drastically. Some areasappear the phenomenon of "labor shortage", while the migrant workers in some areascannot find jobs, which impacts the development of enterprises and the survival of migrant workers. The crime rate of migrant workersrises, and the crimerate of migrant workers' children also rises, causing the loss of people's lives and property and affecting thesociety's stability and harmony. The population in some cities, especially in Beijing, Shanghai, Guangzhou and other first-tier cities, has exceeded the"red line" or is about toexceed the "red line", which will threat the society's normalrunning.

A potential crisis we also shouldpay attention to is that"if the population mobility and migrationpolicy in Chinahas no particularchanges, the flow of populationin 2050 will reach350 millions". It undoubtedlymeans that the number ofmigrant workers in Chinawill continue to increase, and the social problems caused by it will be moreand moreserious!So, some media and experts appeal and recommend: "The population inbig cities of China has seriously overloaded, and the experts recommend control the inflow appropriately," "It is very necessaryto control the population through government policy"3; "The disorderly flow of hundreds of millionsof migrant workers is not a socialprogress but adisastroussetback."4 I alsobelieve that it is imperative for the state to establish the flow regulatory mechanism of migrant workers, to control the flow amount, direction and velocity of migrant workers, and to guidethe orderly flow ofmigrant workers!

\section{ESTABLISH THE FLOW REGULATORY} MECHANISM OF MIGRANT WORKERS, CONTROL THE FLOW OF MIGRANT WORKERS

In this regard,we recommend establish the flow regulatory mechanism of migrant workers of "persuade some to leave, place restrictions on some migrant workers and recommend some migrant workers"according to the actualneedsof city development.

\section{A. Persuade some migrant workers to leave}

According to Yan Qingchun, thedeputy director of theNational Committee on Aging,the totalmigrant workers entered the citiesin 2011 were 250 million,more than $90 \%$ of whichwere temporary workerstemporarilyemployed bythe employers. According to the author's survey in the main city area of Chongqing, mostmigrant workers are "temporary workers" who do not have any fixed working units. ${ }^{5}$ The most typical ones of them are the "Bang Bang Army", shoes 
polishers andscavengers in the main city area of Chongqing, and thehawker stalls in Beijing, Shanghai and Guangzhou. Theoverall workload of Chongqing's "Bang Bang Army"is far from enough! In other words, these people are not very important or even not dispensable for the cities(there is no "Bang Bang Army" inChongqing before the reform and opening up,and there is no "Bang Bang Army" in other cities today, but theurban people'sliving was or is not affected at all), so it can be said that at leastsome of themcan bepersuaded toreturn the rural areas to grow food.

In addition, the "second generation of farmers" who have beenadults but wanderin the cities all the day and do nothingshould be firmly persuaded back to the rural areas for farmingor to work in local places. Of course, what is more humane is to establish a seriesof preferential policies to enable farmers to make moneyat home and truly improve thequality of basic educationin rural areas, so as to attract the migrant workers to return home.

\section{B. Place restrictions on some migrant workers}

According to the Investigation and Monitoring Report of Chinese Migrant Workers in 2011, more than 10 millionfarmers come into cities to workevery year. Amongthese migrant workers, some are the neededand even necessary ormuch-neededtalents for urban construction, while some are not needed or at least not necessary ormuchneededtalents for the urbancommunity! For the latter, the governments of the outflow andinflow areas should all takevarious measures to "place restrictions on some migrant workers"!

Those whohave skills come into the cities- it refers to that those whohave skills can come into the citiesto work. It is required by the policies and regulationspromulgated by the state that, before themigrant workers coming into the cities, the local governmentshould conduct targeted skills trainingfor farmers and issue skill certificate for those who are qualified. The farmers should come to the cities to work with the skills certificate, and obtain theproof ofmigrant workers in the local government(at leastthe township people's governments). When issuing the certificate, the local government should check and verify whether the farmersreallyhave skills. If farmers do have skills, issue the certificate forthem and agree them to come into the cities to work; otherwise, do no issue the certificate for them and do not allow them to come into the cities to work.

Those who have certificate can stay in the cities- the migrant workers who have skills find workin the cities and sign the employment contract with the employment unit can obtain the "Staying permit" or "Residence permit" at the police station with the employmentcontract.

Those who have skills and migrant worker certificate but do not actuallyfind a jobin the cities can leave a message in the personnel exchange center(who has obligations of servingthe migrant workers) and return home for farming while waiting forbefore the deadline!

\section{Recommend some migrant workers}

With the improvement and continuous developmentofour economic situation, some migrant workers are needed to come into the cities to work every year. Especially the labor shortagein the coastal areas indicates that some migrant workers are needed to come into the cities to work every year. The localpeople's governments of the outflow areas should recommendsometalentstoemployment units according to the nationalemployment information. The employers canalso get some needed migrant workers with skills from the outflow areas according to the nationalemployment information.

\section{ESTABLISH THE FLOW REGULATORY MECHANISMS \\ OFMIGRANT WORKERS,CONTROLTHE FLOW OF MIGRANT WORKERS}

In this regard,wesuggest establishing the government service platform, developing township enterprises and cultivating self-employment.

\section{A. Establish the governmentservice platform}

At present, the service platform of Chinese migrant workers is mainly the managementplatform of the public security,labor and social security, health care, family planning, housing and other departments after the migrant workers has come into the cities. Most of these departments do notimplemented the informationsharing andcoordination, and there is no informationsharing mechanism established between different provincesand differentsystems.

It is recommended that the local governments should establish the national network of the government serviceplatform of migrant workers information which relevantdepartmentsactivelyparticipate in, and collect andpublishthe supply and demand information all over the country, to provide accuratesupply and demand information including the wage information for the society, to improve the matchingeffects of recruitment andjob-searching.On the other hand,the local governments should preciselygraspthe flow trajectory ofmigrant workers, and guidethe rational and proper flow of migrant workers timely. Guide according to the classification and take appropriatemeasures to mitigate the employmentandrecruitment difficultiesin some areas.

\section{B. Develop township enterprises to attractmigrant workersto workat home}

The State Council reviewed andissued the Opinions on ResolvingMigrant Worker Problemson January 18, 2012. It points out that we should focus on the present and take the longer view to resolve the migrant worker problems. We should focus on the works in seven areas now, one of which is topromotethe local transfer ofrural labor, develop the townshipenterprises and economy vigorously, to improve theindustrial concentration andabsorptive capacity of populationin small towns, and to expand the local capacity ofemployment transfer. ${ }^{6}$ It actually controls theflow amount and direction ofmigrant workers.

\section{Cultivate self-employment}

The government furtherincreases the encouragement and support efforts to the self-employment of migrant workers at home. The government provides supportin the capital,tax relief,business registration,information consultationand other 
aspects. As to the technicaltraining, the government arranges specialfunds forvocationalskills trainingof farmers, the farmerscan choosethetraining institutions, training contentandtraining time independently, and the government gives somesubsidies andfunding to the trainedfarmers.For example, expand the implementation scale of the "Sunshine Project of Rural Labor Devolved Training", innovate the vocationaltraining methods of migrant workers, conduct the skills training for migrant workers in various channels, and improve especially theability of self-employment of migrant workers. The experience of the county government of Kai County, Chongqing (a country with the largest amount of migrant workers, who has 500000 migrant workers working in all provinces) sets a good example for us. It carried out the "entrepreneurship training" to attract migrant workers to "go home for entrepreneurship". ${ }^{8}$ According to our survey, as to April 2013, the county government of Kaxian has attractedmore than 40000migrant workers to return home for entrepreneurship andworking through a variety ofsupporting andtraining policies. Although the amount is less than onetenth of the migrant workers, the orientation of its policy deserves recognition!

\section{ESTABLISHTHE FLOW RATEADJUSTMENT MECHANISM OF MIGRANT WORKERS,CONTROL THE FLOW RATE OFMIGRANT WORKERS}

In this regard,werecommend plan the growth proportionof population scientifically, improve the efficiency and reducethe amount of labor used and outputmigrant workers to foreign counties.

\section{A. Plan the growth proportionof population scientifically}

Everycity, especially Beijing, Shanghai, Guangzhou and other first-tier cities should make the development planning ofurban population and control the population growth orderly,especiallythe growth ofmigrant workers. Allocate the annual growth proportion of population and accommodate the migrant workers scientificallyaccording tothe city's carrying capacity and development need.

\section{B. Improve the efficiency and reducethe amount of labor used}

Enterprises shouldtap thepotential of human resources, maximize the efficiency and reducethe amount of labor used, to share the worries of the country and to alleviate the pressures onurban society. Enterprises canmaximize the mobilization of employees'working enthusiasm through moral encouragementand material rewards.As the saying goes, there must be brave man under generous rewards. Furthermore, although the human capacityis limited,the human potentialis huge. As long as enterprises can mobilizethe human potential properly andwell, they can also reducethe amount of labor used and improve the work efficiency!

\section{Outputmigrant workers to foreign counties}

Chinais alarge country with 1.3 billion people, and is rich in human resources.Deng Xiaopingsaid that the door of China's reform and opening-up would bebigger and bigger, and the door is used togo in andout. We should not just welcome others to come in, but also send offour own people to go out. As for the outflows of population to foreign countries, we should adopt the policy of "proper control" to relax the restrictions on the outflows of population, which can reduce the illegal immigration and thedomesticpopulation pressure. The countrycanconclude bilateralor multilateralpopulation mobility agreements with other countries, and set up the population mobility agreements or standards for two or more countries on other bilateralor multilateralpopulation mobility agreements with the principles of equality and mutual benefit and of negotiated consensus, to guide the legitimate outflow of extra people andcontribute to the developmentof the world economy.

\section{Acknowledgement}

Periodical achievements of the National Social ScienceFund Project in 2012:Research on the new social problems caused by the migrant workers'children cominginto the city to study(approved: $12 \mathrm{XSH} 005)$.

\section{References:}

[1] Ruan Yulin. It is said in the report that the Chinesemobile populationwill be up to350 millionin 2050[EB/OL]. www.chinanews.com, May 30, 2011.

[2] The population in China'sbig cities has severelyoverloaded andexpertsrecommendappropriate restrictions oninflows [EB/OL]. www.chinagate.com.cn, January 26, 2010.

[3] Li Xizhang.The disorderly flow ofhundreds of millionsof migrant workers is not a socialprogress but a disastroussetback [EB/OL] http://wht073100.blog.sohu.com/205979853.html, March 03, 2012.http://i.sohu.com/p/=v2=dQAvNTawHDhz2MM0cHUuY29t/

[4] 5. The survey shows that the empty nesthouseholdsin rural areashave reached $45 \%$ and the pension is not as good as in the past [EB/OL]. http://gb.cri.cn, December 06, 2012

[5] Opinions on ResolvingMigrant Worker Problems [EB/OL] http://www.gov.cn, March 27, 2006.

[6] WANG Jufang, Sheng Yuhong, Zhao Tianwei. The returning migrant workers of Kaixian, Chongqing areeagerto participate in the entrepreneurship training [EB/OL]. http://gb.cri.cn, February 25, 2009

[7] Zhang Fang. Millions of people of Kaixianreturn to home for entrepreneurship and achieve a productive investment of nearly 50 billion yuan [EB/OL]. http://www.cqnews.net, March 1, 2012.

[8] Mobile populationProblems [EB/OL]. http://www.9ask.cn, June 28, 2010. 
